\title{
Teologia Mariana: Contribuições para a reflexão sobre a humanização de Deus
}

\author{
Marian Theology: Contributions to the reflection on \\ the humanization of God
}

Lúcia Pedrosa-Pádua

\section{Resumo}

A teologia mariana contribui para evidenciar a lógica encarnatória da ação divina, que transforma o ser humano e a história a partir de dentro, doando-lhes uma vida nova e um futuro insuspeitado. Por lógica encarnatória entendemos a lógica kenótica de Deus, pela qual, em Jesus Cristo, Ele se humaniza, "desce", "entra", "submerge" em nossa humanidade, faz-se escravo, transpassa a humanidade humilhada e instaura dinâmicas de uma vida nova.

O texto inicia com um estudo bíblico da perícope da Anunciação, através da qual é possível afirmar que a graça da mulher Maria é servir à humanização de Deus; em seguida apresenta como a Igreja antiga elaborou uma teologia mariana na qual a maternidade de Maria é relacionada à Kénosis do Verbo; analisa alguns elementos antropológicos decorrentes da lógica encarnatória da graça, a partir dos significados antropológicos da resposta de Maria à proposta divina; indica algumas consequências da humanização de Deus para a espiritualidade cristã e finaliza com uma reflexão sobre o evento do encontro da imagem de N. Sra. Aparecida, apresentado como metáfora da lógica encarnatória da graça de Deus na vida dos pobres. Este evento conclama a uma kénosis da Igreja como pressuposto para um verdadeiro discipulado.

Palavras-chave: Teologia mariana. Encarnação. Kénosis. Humanização de Deus. 


\begin{abstract}
Marian theology contributes to sustain the incarnation logic of divine action, which transforms human beings and history from within, granting new life and unsuspected future. Incarnation logic refers to the kenotic logic of God, through which He humanizes in Jesus Christ, "descends", "enters", "submerges" into our humanity, enslaves Himself, pierces humiliated humanity and establishes the dynamics of a new life.

The text begins with a biblical study of the Annunciation pericope, through which is possible to affirm that the grace of Mary is to serve to the humanization of God; then it presents how the early Church elaborated a Marian theology where the maternity of Mary is related to the Kenosis of the Word; following it analyzes some anthropological elements resultant of the incarnation logic of grace, starting from the anthropological meanings of the answer of Mary to the divine proposition; subsequently it indicates some consequences of the humanization of God to the Christian spirituality and concludes with a reflection on the event of the encounter of the image of Our Lady of Aparecida, presented as a metaphor for the incarnation logic of the grace of God in the life of the poor. This event beckons a kenosis of the Church as presumption for a true discipleship.
\end{abstract}

Keywords: Marian theology. Encarnation. Kenosis. Humanization of God.

\title{
Introdução
}

A mariologia, ou teologia mariana, hoje se pergunta sobre a maneira de articular os enunciados mariológicos com os conteúdos principais da fé cristã. Esta tarefa, iniciada sob as orientações do Concílio Vaticano II, vem se mostrando frutuosa e precisa ser aprofundada com coragem. Dentre os lugares da mariologia, surge a reflexão referente à salvação de Jesus Cristo, a soteriologia. ${ }^{1}$ Maria é então vista como aquela que, por graça, serve à redenção da humanidade ao engajar-se na humanização de Deus.

Sabemos que a reflexão sobre a salvação sofreu, ao longo dos séculos, diversos reducionismos. A graça foi reduzida a um auxílio interno para agirmos

${ }^{1}$ Cf. MUller, A.; SATTler, D. "Mariologia". In: SCHNEIDER, T. (Org.). Manual de Dogmática. Vol. II. 4a ed. Petrópolis: Vozes, 2009, pp. 144-145. 
corretamente, que nos santifica interiormente quando acolhida por nós, e que constitui a garantia de nossa futura salvação, se dela dispusermos no momento de nossa morte. Nesta redução, a concepção de salvação se viu marcada por um individualismo que ignora a dimensão social da ação divina, por uma tendência espiritualista que desconsidera o enraizamento cósmico-corpóreo, e por um acento essencialista que silencia a dimensão histórico-cultural. A humanização de Deus em Jesus Cristo fica externa e distante desta concepção de salvação e, ainda mais, do cotidiano e da espiritualidade cristãos. ${ }^{2}$ A teologia mariana contribui na superação destes reducionismos porque obriga a trazer a humanização de Deus para o centro da reflexão teológica e da espiritualidade.

Ao olhar e refletir sobre a figura de Maria, a jovem de Nazaré, a teologia mariana contribui para localizar a iniciativa divina da autocomunicação de Deus em Jesus Cristo em sua singularidade e radicalidade. Evidencia a lógica encarnatória da ação divina, que se mostra lógica transformadora a partir de dentro do ser humano e da história - é a partir daí que Deus suscita uma vida nova e um futuro insuspeitado.

Este artigo apresenta aspectos da teologia mariana que colocam os mistérios da vida de Maria como expressão da lógica encarnatória da graça de Cristo. Por lógicas encarnatórias entendemos a lógica kenótica de Deus, expressa em Fl 2,6-11. Por este movimento, em Jesus Cristo, Deus se esvazia e humaniza, desce, abaixa-se, entra, submerge em nossa humanidade histórica e culturalmente enraizada. Em Jesus Cristo, Deus faz-se escravo, assume a fragilidade humana e a humanidade humilhada para, a partir deste lugar, instaurar dinâmicas de uma vida nova, no Espírito. Na vida de Maria ecoa esta lógica de encarnação, em dois movimentos: sua resposta a Deus é um serviço à encarnação e, ao mesmo tempo, sua própria vida é a expressão da vida nova que Deus oferece ao mundo. Por isso, Maria pode ser fonte de inspiração para a espiritualidade e o discipulado.

O nosso texto traçará o seguinte caminho: iniciará com um estudo bíblico da perícope lucana da Anunciação, através da qual é possível afirmar que a graça da mulher Maria é servir à humanização de Deus; em seguida veremos como a Igreja antiga elaborou uma teologia mariana na qual a maternidade de Maria é relacionada à Kénosis do Verbo; analisaremos alguns elementos antropológicos decorrentes da lógica encarnatória da graça, a partir dos significados antropológicos da resposta de Mariaà proposta divina; indicaremos algumas consequências da humanização de Deus para a espiritualidade cristã

\footnotetext{
${ }^{2}$ Cf. MIRANDA, M. F. A salvação de Jesus Cristo: a doutrina da graça. São Paulo: Loyola, 2004, p. 31ss.
} 
e finalizaremos com uma reflexão sobre o evento do encontro da imagem de N. Sra. Aparecida como metáfora da lógica encarnatória da graça de Deus na vida dos pobres e convite a uma Igreja kenótica e discipular.

\section{A graça da jovem Maria: servir à humanização de Deus}

Iniciemos esta abordagem pelo estudo da narrativa da Anunciação e, nela, a saudação do anjo a Maria. Veremos como servir à humanização de Deus foi a graça de Maria, a mãe do Senhor.

R. E. Brown, ${ }^{3}$ em seu estudo sobre a saudação, mostra como o sentido do texto de Lc 1,28 é ampliado e interpretado na segunda declaração angélica, em Lc 1,30-31, da forma reproduzida abaixo ${ }^{4}$ :

\begin{tabular}{|l|l|}
\hline Lc 1,28 & Lc 1,30-31 \\
\hline $\begin{array}{l}\text { Chaire (Salve) = Alegra-te } \\
\text { kecharitomene (favorecida) = Cheia } \\
\text { de graça }\end{array}$ & $\begin{array}{l}\text { Encontraste favor (charis) junto } \\
\text { a Deus }\end{array}$ \\
O Senhor está contigo & Conceberás em teu ventre \\
\hline
\end{tabular}

O mensageiro de Deus, no texto de Lucas saúda Maria, "Salve!", que pode ser traduzido por "alegra-te". Esta alegria está relacionada com o ser favorecida por Deus, kecharitomene, traduzido como "ó favorecida", agraciada, cheia de graça. Diante destas palavras Maria fica intrigada e se pergunta o significado desta saudação (v. 29). Que alegria será esta? Ao que o anjo responde: "Não tenhas medo, encontraste graça junto a Deus. E eis que conceberás em teu seio e darás à luz um filho" (v. 31).

O favor de Deus - a graça de Deus - está assim relacionada com a concepção de Jesus. A alegria se dá no contexto do anúncio de uma notícia inesperada, divina e favorável. O Senhor está com Maria, sua presença é benevolente, não precisa ser temida. Maria foi agraciada, favorecida, por Deus, e esta graça (favor) é conceber o Messias.

\footnotetext{
${ }^{3}$ Cf. BROWN, R. E. O nascimento do Messias: comentários das narrativas da infância nos evangelhos de Mateus e Lucas. São Paulo: Paulinas, 2005, pp. 382-389.

${ }^{4}$ Ibidem, p. 383.
} 
Assim, se Maria é cheia de graça é porque a graça por ela recebida é a plenitude do favor de Deus, o Cristo. Mas é preciso estar atento: esta graça da concepção não é um objeto ou uma função, mas sim uma relação radical com o Filho que em seu seio assume a humanidade, realizada no Espírito. Esta relação, assumida na concepção, desenvolve-se ao longo de toda a vida de Maria, passando pelo seguimento do próprio filho, de quem ouvia e colocava em prática as palavras (Lc 11,28), pela cruz, pela participação na jovem Igreja nascente e continua, misteriosamente, na comunhão dos santos.

Quem poderia imaginar algo semelhante? $\mathrm{O}$ contraste não poderia ser maior. Maria, a jovem camponesa, de família pobre, prometida em casamento, da pequena Nazaré, é convidada a inserir-se no mistério da vinda do Cristo, graça de Deus em pessoa. Ou, por outro ângulo, o Filho de Deus faz-se pequeno, frágil e indefeso no seio da jovem de Nazaré.

\section{Maternidade para a kénosis}

De fato, é sabida a dificuldade da antiguidade com relação à realidade da encarnação. A concretude e historicidade da cruz são ora "escândalo", ora "loucura" (1 Cor 1,23). As tendências gnósticas de desvalorização do corpo e da matéria se faziam fortes e presentes. Assim, negavam a encarnação do Filho de Deus no seio de Maria: "ou porque Jesus não era o Filho de Deus (...), ou porque o fruto do seio de Maria não era rigorosamente dela (ex Maria), não se encarnou nela, e sim simplesmente passou por ela (per Mariam)". ${ }^{5}$

Diante disto, Padres importantes nos primeiros séculos ${ }^{6}$ tiveram que defender este real abaixamento de Deus a nós, o esvaziamento de Deus em sua humanização.

Assim, Santo Irineu observava como, se o Verbo não tivesse se feito realmente homem, todo o sistema da redenção cairia por terra. Por isso, considera fundamental o texto de Gálatas 4,4: "Deus enviou o seu Filho, nascido de mulher". O Verbo de fato se fez homem, encarnou-se no seio de uma mulher, Maria.

Da mesma forma Hipólito situa o mistério da encarnação no coração da ação redentora de Deus:

\footnotetext{
${ }^{5}$ GARCIA PAREDES, J. C. R. Mariologia. Síntese bíblica, histórica e sistemática. São Paulo: Ave-Maria, 2011, p. 236.

${ }^{6}$ Cf. Ibidem, pp. 237-238.
} 
Sabemos que ele assumiu o corpo da Virgem, que revestiu o homem velho mediante uma nova criação, que passou através de toda idade da vida, para se converter em norma de toda idade... Sabemos que esse homem nasceu de uma massa como a nossa: se não tivesse sido de nossa mesma massa, vã seria a lei de imitar o mestre. Se esse homem tivesse sido de outra substância, por que me teria mandado tais coisas a mim, que sou fraco por natureza? Seria bom e justo? ${ }^{7}$

Assim sendo, nos séculos II e III a maternidade de Maria é entendida como o meio escolhido por Deus para o abaixamento, Kénosis, de Deus até nós. Deus se faz, nas palavras de Hipólito, transcritas acima, “de nossa mesma massa", a massa de Maria, com vistas a uma nova criação.

Maria entrará na história da fé cristã por este mistério da humanização do Verbo de Deus, em Jesus. Os artigos do Símbolo dos Apóstolos, credo cristão anterior aos concílios ecumênicos, vão mencioná-la: "Creio (...) e em Jesus Cristo, seu único Filho, nosso Senhor, que foi concebido pelo poder do Espírito Santo, nasceu da Virgem Maria (...)". E, mais tarde e mais expressamente, o Símbolo Niceno-Constantinopolitano (ano 381) se refere a ela na menção do mistério da encarnação:

Creio em um só Senhor, Jesus Cristo, Filho Unigênito de Deus, / nascido do Pai antes de todos os séculos: Deus de Deus, luz da luz, / Deus verdadeiro de Deus verdadeiro, / gerado, não criado, consubstancial ao Pai. / Por ele todas as coisas foram feitas. / E por nós, homens, e para nossa salvação, desceu dos céus: e se encarnou pelo Espirito

Santo, / no seio da Virgem Maria, e se fez homem.

Os Concílios antigos vão enunciar que ela é a Theothokos (Éfeso, 431), ${ }^{8}$ a "Mãe de Deus", Mãe do Verbo encarnado. E que o Filho foi gerado, segundo a humanidade, de Maria Virgem, para a nossa salvação (Calcedônia, 451). ${ }^{9}$

Assim sendo, a fé cristã nos diz que Deus insere esta mulher, Maria, no epicentro do seu desígnio salvífico. E o faz mediante o convite a uma relação e

\footnotetext{
${ }^{7}$ Hipólito. Philosophoumena, apud. GARCIA PAREDES, J. C. R. Mariologia. Síntese bíblica, histórica e sistemática, p. 237.

8 DENZINGER, H. Compêndio dos símbolos, definições e declarações de fé e moral (atualizada por J. Konings, com base na $43^{\mathrm{a}}$ ed. Alemã [2010], preparada por P. Hünermann e H. Hoping). $2^{\text {a }}$ ed. rev. e ampl., nn. 251.252. São Paulo: Paulinas/Loyola, 2013, pp. 97 e 100. De ora em diante esta obra será abreviada como DzH, seguida dos números correspondentes.

${ }^{9}$ Ibidem, pp. 112-113. DzH 300.301.
} 
missão. Deus entra em sua vida convidando-a à maternidade divina, pela qual o mistério de Maria atinge a toda a humanidade. Nunca mais Maria estaria separada de seu filho, o Filho de Deus. Clara Temporelli nos dirá que "Maria se converte numa peça-chave da fé cristã”, no sentido de que, em sua resposta a Deus, "é ela quem dá carne humana ao Deus encarnado. Ela nos permite enraizar o cristianismo na história". ${ }^{10}$

A maternidade de Maria está a serviço do desígnio histórico-salvífico que implica toda a humanidade. Por sua entrega, Maria se põe a serviço de Deus e de seu projeto de autocomunicar-se aos seres humanos, a fim de que estes descubram a plenitude da realização que podem alcançar por meio de sua autoentrega a Deus.

Autocomunicação divina e autoentrega a Deus da parte da mulher Maria são realidades unidas. Maria é o ser humano que alcançou a plenitude na doação de si a Deus, e coloca-se no ponto de interseção entre Deus e o ser humano; nela se dá uma ampla rede de relações que têm a ver com Deus e com sua graça libertadora, com a história e com a humanidade. Em sua maternidade, Maria recebeu a máxima autocomunicação de Deus, e Deus realizou, no Espírito, uma comunhão plena com um ser humano.

Quando Jesus é reconhecido como Messias, como Filho de Deus, a figura de Maria, sua maternidade, o fato de gerá-lo e dá-lo à luz, revestem-se de transcendência. Tudo em Maria adquire um novo significado. A transcendência da maternidade de Maria se expressa no fato de ter gerado um homem que é Deus encarnado, por isso ela é Theotokos.

Esta grandeza evidencia a realidade da humanização de Deus na humanidade de Maria. É grandeza paradoxal, compreendida no interior da sabedoria do Evangelho.

\section{Deus se humaniza mediante um diálogo humanizador: signifi- cados antropológicos do sim de Maria}

A afirmação de Maria como Mãe de Deus não dilui, ao contrário, explicita, a relação entre Deus e Maria baseada na proposta e dom que suscitam respostas. É no interior de um diálogo entre Maria e o anjo mensageiro de Deus, Deus mesmo por seu Espírito, que ela, respondendo, por graça, ao dom recebido, consente a esta missão, dizendo eis-me aqui, "faça-se" (Lc 1,38).

10 TEMPORELLI, C. Maria, mulher de Deus e dos pobres. Releitura dos dogmas marianos. São Paulo: Paulus, 2010, p. 23. 
Vejamos algumas dimensões desta resposta, que nos aponta direções da humanização suscitada por Deus.

\section{Um $\operatorname{sim}$ a um chamado histórico-profético}

$\mathrm{Na}$ Anunciação, encontramos um chamado de Maria para uma missão de Deus, profética. ${ }^{11}$ A lógica encarnatória da ação divina, graça, não teme, ao contrário, deseja assumir o humano e a história. E o faz a partir do pequeno, da jovem camponesa de Nazaré.

Maria recebe a missão de participar, de maneira decisiva, no desígnio salvífico divino. O anúncio do nascimento de Jesus, o Filho de Deus, é, ao mesmo tempo, o chamado profético de Maria de ser interlocutora e aliada de Deus, ao dar voz e carne ao mistério oculto até então. Mostra até que ponto um ser humano é capaz de comunhão e diálogo com Deus.

O sim de Maria marca o início de um tempo novo, do acontecimento de Deus na história, e na história concreta de Maria e do povo de Israel, que ela representa.

\section{Um $\operatorname{sim}$ aos processos do Espírito}

Não pode nos passar despercebido que a resposta do mensageiro a Maria não foi na linha da explicação física de "como se fará isso"; ela consistiu

${ }^{11}$ Cf. JOHNSON, E. Nossa verdadeira irmã. Teologia de Maria na comunhão dos santos. São Paulo: Loyola, p. 302ss. Esta autora mostra (pp. 304-306) como, no AT, as narrativas do chamado dos profetas seguem cinco elementos bem definidos, presentes também no relato da anunciação. Primeiro, a saudação por parte de um mensageiro de Deus. Em seguida, quem a recebe reage com espanto ou medo, sendo encorajado a não temer. O terceiro elemento é o anúncio da intenção de Deus e do resultado futuro. Quarto, quem recebe o chamado faz uma objeção. Finalmente, a narrativa termina com um sinal do poder de Deus que dá confiança a quem o recebe. Estes cinco elementos estão presentes na narrativa do chamado de Moisés, em Ex 3,1-14, ou de Gedeão, em Jz 6,11-24.

No Evangelho de Lucas, encontramos todos estes cinco elementos das narrativas das vocações proféticas no chamado de Maria. Primeiramente, o anjo aparece e a saúda, "Alegra-te, ó tu que tens o favor de Deus, o Senhor está contigo" (v. 28). Em seguida, Maria fica apreensiva, "ela ficou perturbada, e se perguntava o que podia significar esta saudação" (v. 29), sendo então encorajada, "não temas, Maria, pois obtiveste graça junto a Deus" (v. 30). Vem então o terceiro elemento, o anúncio da intenção divina: "eis que engravidarás e darás à luz um filho, que será grande e será chamado filho do Altíssimo... o seu Reino não terá fim” (vv. 31-33). Maria então coloca uma objeção, “como se fará isso..." (v. 34), ao que o mensageiro responde com a promessa do Espírito Santo, enfatizada com o sinal da gravidez de Isabel, já idosa (vv. 35-37). 
na promessa da presença do Espírito: "O Espírito virá sobre ti” (Lc 1,35), ou seja, a força criativa de Deus a acompanhará. Deus é o que possibilita uma novidade radical. O Evangelho acrescenta que "o poder do Altíssimo te cobrirá com a sua sombra" (Lc 1,35). Esta sombra tem sentido positivo, tratase da sombra benfazeja de Deus, manifesta a proteção divina sobre Maria, não como quem a blinda das dificuldades, mas como a presença do próprio Deus que a fortalece e em quem se pode confiar. ${ }^{12}$ Para Ele, "nada é impossível" (Lc 1,37). A teóloga E. Johnson observa que Maria é posta numa "relação profunda e alerta com o Espírito de Deus", ${ }^{13}$ e representa aqueles de quem o Espírito-Sabedoria se aproxima: “Ao longo dos tempos, a sabedoria passa nas almas santas para formar amigos de Deus e profetas" (Sb 7,27).

Na Exortação Apostólica Evangelii Gaudium, o Papa Francisco coloca, como um critério de ação, a superioridade do tempo sobre o espaço (EG n. 223). Segundo este princípio, vale mais ocupar-se com iniciar processos do que com possuir espaços. Trata-se de um princípio pneumatológico porque traz um convite a apostar nos dinamismos desconcertantes do Espírito, como Maria. E para isso é necessário deixar os espaços adquiridos. Como escreveu W. Kasper, na Igreja de hoje, é preciso "despedir-se e partir", ${ }^{14}$ deixando as cargas inúteis, buscando a autenticidade do Evangelho. Para ele, um novo pôr-se a caminho só será possível com "uma renovação espiritual que se nutre das fontes, uma sólida reflexão teológica e uma mentalidade eclesial". ${ }^{15}$ A entrega aos caminhos do Espírito, em escuta atenta e amorosa, tem em Maria um testemunho privilegiado.

\section{Um sim livre que desenvolve liberdade}

O consentimento de Maria é dado livremente. Sua resposta manifesta sua fé consciente e ativa, de alguém que ouve a palavra de Deus e a guarda. "Eu sou a serva do Senhor. Aconteça-me segundo a sua Palavra" (Lc 1,38). Eis-me aqui. Fiat.

Em Maria, como em tantos testemunhos bíblicos, Deus manifesta que sua comunhão com os homens e mulheres acontece mediada pela palavra,

\footnotetext{
${ }^{12}$ Cf. BROWN, op. cit., p. 390. A sombra de Deus significa a presença divina.

${ }^{13}$ JOHNSON, op. cit., p. 309.

${ }^{14}$ KASPER, W. A Igreja católica. Essência, realidade, missão. São Leopoldo: UNISINOS, 2012, p. 413.

${ }^{15}$ Ibidem, p. 415.
} 
pela liberdade e pela gratuidade. O teólogo belga A. Gesché já observou que Deus prefere a transparência na relação conosco, não os silêncios temerosos ou armadilhas. No diálogo com Deus não há imposição nem violência e nada está pré-determinado. Exercer a liberdade faz parte da vocação da pessoa humana, trata-se de um "direito", não é um ato de insubmissão. A liberdade é obrigatória, constitutiva da humanidade. Na relação com Deus há gratuidade - graça - não subserviência. Deus é aquele que convida a pessoa a tomar a palavra. $^{16}$

Assim deve ser interpretado o sim de Maria: como liberdade dos que tomam a palavra, como gratuidade dos que servem fielmente a Deus, na linhagem de Abraão, de Moisés e de Débora, culminando com o servo do Senhor, em Isaías. E, no seguimento do seu filho, como discípula perfeita, Maria qualifica seu serviço com o Messias Servidor. No relato das Bodas de Caná, ao dizer aos servos "Fazei tudo o que ele vos disser" (Jo 2,5), Maria os convida a ter a mesma atitude dela, a de colocar em prática o que diz o Servo de Deus. É um ato de auto-determinação e autonomia pessoal, que muda sua vida; Maria se doa e, nesta doação, inaugura uma humanidade redimida e um mundo novo.

\section{Um sim no meio do mundo que luta pela vida}

Maria responde a Deus, que lhe fala diretamente. Interessante notar o que algumas teólogas já notaram: Maria não busca conselhos de nenhuma figura de autoridade masculina para responder. Ao contrário do que acontece com Zacarias na anunciação do nascimento de João Batista (Lc 1,5-25), o cenário não é sacerdotal, os eventos não se passam no Templo. O espaço de Maria é feminino e laical. Acontece na cidade de Nazaré, no contexto de uma camponesa pobre, participante das esperanças de vida e liberdade de seu povo. É ali que Maria é chamada a responder à relação que Deus lhe oferece, como qualquer profeta. Ali deve dizer o seu "eis-me aqui".

\section{Um sim potencializador}

O sim de Maria potencializa suas melhores energias, pois é pronunciado no interior do diálogo oferecido por Deus. O profeta não pode

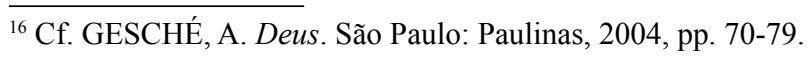


se calar, a graça acolhida potencializa, gera vida nova, empodera para ações audazes. O Evangelho nos diz que "Maria partiu às pressas, rumo à região montanhosa" (Lc 1,39) para se encontrar com Isabel, sua parenta. É neste contexto do encontro entre as duas mulheres, cheias do Espírito, que Isabel proclamará o cântico de reconhecimento da graça de Deus em Maria e Maria proclamará o Magnificat, um cântico que é, ao mesmo tempo, louvor à graça misericordiosa de Deus e um cântico que proclama o favor de Deus para com os pobres, os humilhados. ${ }^{17}$ No Cântico do Magnificat, há a proclamação gozosa da justiça de Deus, com inversão radical da situação dos pobres e marginalizados. Maria será a porta-voz da justiça de Deus e do socorro de Israel, descrita em tons enérgicos: Deus intervém com força, dispersa, depõe (os poderosos), exalta (os humildes), cobre de bens, despede (os ricos sem nada). Um cântico que denota uma resistência desafiadora aos poderes do mal, e com fortes conotações econômicas e políticas. ${ }^{18}$

Com a graça de Deus, o mundo começa de novo, mas de uma forma diferente, devido à força irreprimível do Reino de Deus que irrompe naquele que Maria leva em seu seio.

Algumas autoras observam, ao unir a anunciação com a visitação, como Maria é a mulher do sim - fiat - na Anunciação, e também a mulher do não a toda injustiça que gera a intervenção de Deus, no Magnificat. ${ }^{19}$

Enfim, a acolhida de Maria à graça de Deus, seu sim a ser a mãe do Messias servidor, insere-se na mesma lógica do Espírito que a projeta, para além da maternidade biológica, a escutar a palavra do Messias Servidor e colocá-la em prática. A mãe, Maria, segundo os Evangelhos, é também mulher, discípula do Messias-Servidor e mãe de discípulosservidores. ${ }^{20}$

\footnotetext{
17 R. E. Brown observa que a expressão tapeinosis, que significa humildade, humilhação, pobreza, expressa a situação dos perseguidos e oprimidos, situação da qual Deus os liberta no AT. Tapeinosis foi utilizada para traduzir o hebraico 'oni, palavra relacionada com o conceito dos anawim. Maria representa aqui os pobres e humilhados pela perseguição e opressão. Cf. BROWN, op. cit., p. 390ss.

${ }^{18}$ Cf. JOHNSON, op. cit., pp. 319-329.

${ }^{19}$ Cf. BINGEMER, M. C.; GEBARA, I. Maria, Mãe de Deus e mãe dos pobres. Petrópolis: Vozes, 1987.

${ }^{20}$ PEDROSA-PÁDUA, L. "Itinerários de Maria. Inspiração para uma Igreja "em saída"”. Convergência 481 (2015), pp. 321-335.
} 


\section{Importância da teologia mariana para uma espiritualidade de encarnação}

Em Maria a Palavra se fez "carne", concretude. Por sua fé, nela "se cumpriu o que foi dito da parte do Senhor" (Lc 1,45). Há uma vida transformada e plasmada pela Palavra ouvida, realizada e frutificada. Não se trata de uma fé superficial, intelectual ou moral. Trata-se de uma experiência profunda e transformante que unifica as forças num novo ser e numa nova prática. A fé de Maria foi uma fé operante, que "opera pela caridade" (G1 5,6). Maria, nas palavras de C. Boff, “"praticou' a Palavra ouvida (cf. Lc 11,28), enquanto transformou essa Palavra em ação, vida e história". ${ }^{21}$

Maria lembra que o cristianismo é "religião da encarnação", e é

um poderoso dique contra as tentativas de esvaziar o cristianismo de seu conteúdo 'encarnatório', isto é, de sua dimensão humana, concreta, histórica. Ela fez e faz Deus 'baixar à terra'. Ela lembra que o cristianismo, como 'religião da encarnação', deve assumir toda a realidade - seja ela humana, histórica ou cósmica - no abraço do Pai, do Filho e do Espírito Santo. ${ }^{22}$

Assim, a contemplação e a reflexão mariana não permitem esquecer a salvação de Deus, marcada pela "loucura" e "escândalo" do Cristo crucificado. Revelação de um Deus que planta, na criação e na história, o sacrifício do esplendor da glória divina e associa o poder divino ao amor e paixão incondicionais pela humanidade.

Uma expressão forte encontramos no documento de Puebla. Ele se refere a Maria como "o ponto de união entre o céu e a terra". ${ }^{23}$ Ela é o "laço que une divindade e humanidade e que conjuga fé e política". ${ }^{24}$

O mesmo princípio da encarnação orienta a espiritualidade cristã.

\footnotetext{
${ }^{21}$ BOFF, C. Mariologia Social. O significado da Virgem para a Sociedade. São Paulo: Paulus, 2006, p. 469.

${ }^{22}$ Ibidem.

${ }^{23}$ III CONFERÊNCIA GERAL DO EPISCOPADO LATINO-AMERICANO. A Evangelização no presente e no futuro da América Latina. Conclusões: PUEBLA (texto oficial da CNBB; apresentação didática: Pe. J. B. Libânio). $5^{\text {a }}$ ed. São Paulo: Loyola, 1979, n. 301. De ora em diante, este Documento será citado como Documento de Puebla, seguido do número correspondente à citação.

${ }^{24}$ BOFF, C. op. cit., p. 469.
} 
Os cristãos geram em seu coração o Cristo vivo cujo Espírito já os habita e o encarnam no mundo. Esta é a grande vocação da espiritualidade cristã, dos discípulos e missionários de Cristo - buscar os caminhos concretos da encarnação do amor salvador de Jesus nas mediações aparentemente tão prosaicas e intranscendentes da vida, como podem ser as mediações familiares, amorosas, comunitárias, sociais, econômicas ou políticas.

Maria é símbolo da fé que se encarna nas realidades que se apresentam sempre tão relativas e precárias, carentes da salvação de Deus. Estas são a precariedade e fragilidade assumidas por Deus ao humanizar-se, ao fazer-se fragilidade humana, ao fazer-se "carne". Todas estas realidades foram, pela encarnação do Verbo, assumidas por Deus e, para tal, Maria foi a grande mediadora. C. Boff diz que estas realidades podem e devem ser assumidas pela fé dos cristãos, que constitui na história uma espécie de "encarnação continuada e ampliada do Verbo". ${ }^{25}$

Nesta encarnação, a vida é gerada. Vida de cada um, das comunidades, da Igreja. Neste sentido, a maternidade de Maria é o protótipo da maternidade de cada cristão e da Igreja. Como uma mãe dá a seu filho a vida preparada por Deus, do mesmo modo a Igreja prepara para os que crêem, que no Batismo morrem com Cristo e nele ressuscitam para uma vida incorruptível, o espaço no qual se deve tornar vivenciável uma existência redimida. É o Cristo vivo que é gerado nos corações pelo anúncio da Palavra, pelos sacramentos, pelo testemunho de vida, pela solidariedade, pela opção preferencial pelos pobres, pelo cuidado com a casa comum - nossa mãe terra. ${ }^{26}$

Vale à pena nos lembrarmos da relação que o Documento de Puebla faz entre Maria e a encarnação do Evangelho, por ter sido a Conferência Episcopal Latino-Americana que melhor explicitou esta articulação. Tratase de um ponto central para a espiritualidade cristã, um verdadeiro antídoto contra espiritualidades que desconsideram o compromisso radical de Deus com a comunidade humana, com a história e com todo o mundo criado.

Ela [Maria] cuida que o Evangelho nos penetre intimamente, plasme nossa vida de cada dia e produza em nós frutos de santidade. ${ }^{27}$

\footnotetext{
${ }^{25}$ Ibidem, p. 470.

${ }^{26}$ MURAD, A. Maria, toda de Deus e tão humana: compêndio de Mariologia. São Paulo/ Aparecida: Paulinas/Santuário, 2014, pp. 140-141.

${ }^{27}$ Documento de Puebla, n. 290.
} 
Deus se fez carne por meio de Maria, começou a fazer parte de um povo, constituiu o centro da história. Ela é o ponto de união entre o céu e a terra. ${ }^{28}$

Sem Maria desencarna-se o Evangelho. ${ }^{29}$

Esta Igreja que com nova lucidez e nova decisão quer evangelizar no fundo, na raiz, na cultura do povo, volta-se para Maria para que o Evangelho se torne mais carne, mais coração na América Latina. ${ }^{30}$

Em todas as afirmações acima ecoa o convite a ver Maria em chave de humanidade livre e comprometida com o Evangelho encarnado na comunidade humana.

\section{A imagem de Aparecida encontrada na lama do rio: convite do Papa Francisco à kénosis como caminho discipular da Igreja}

Não podemos finalizar este artigo sem uma menção à imagem de N. Sra. Aparecida, padroeira do Brasil, há 300 anos encontrada nas águas do Rio Paraíba. Nas circunstâncias deste encontro se renova a memória daquela mulher que proclamou a graça do Deus que se coloca ao lado dos humilhados no evento da encarnação.

Foi o Papa Francisco, em seu discurso aos bispos do CELAM, reunidos em San Salvador, ${ }^{31}$ quem lembrou como Nossa Senhora Aparecida nos "submerge em um caminho discipular". Para ele, a narrativa do encontro da imagem é uma escola que estabelece orientações para o discípulo e para uma Igreja discípula. E sobre isto, Francisco destaca três aspectos.

O primeiro aspecto diz respeito aos pescadores, um pequeno grupo que enfrentava o trabalho diariamente e, ao mesmo tempo, a incerteza do bom resultado da pesca. Homens responsáveis por levar o alimento a suas famílias, conhecedores da generosidade do rio, mas também conscientes da imprevisibilidade da pesca e da agressividade do transbordamento dos rios.

\footnotetext{
${ }^{28}$ Documento de Puebla, n. 301.

${ }^{29}$ Ibidem.

${ }^{30}$ Documento de Puebla, n. 303.

${ }^{31}$ PAPA FRANCISCO. "Carta del Santo Padre Francisco a los participantes em la XXXVI Asamblea General del Consejo Episcopal Latinoamericano" (CELAM, 9-12/05/17, San Salvador). Disponível em: <http://w2.vatican.va/content/francesco/es/letters/2017/documents/ papa-francesco_20170508_lettera-plenaria-celam.html>. Acesso em 13 de maio de 2017.
} 
Estes pescadores, diz Francisco, vivem como tantos trabalhadores que saem para ganhar a vida, com longas jornadas de trabalho, sem ter controle sobre os resultados e, ainda menos, sujeitos à "inclemência gerada por um dos pecados mais graves que golpeiam o nosso continente: a corrupção, essa corrupção que arrasa vidas submergindo-as na mais extrema pobreza". De forma análoga aos pescadores, os trabalhadores enfrentam o "transbordamento" de muitos que não precisam, como eles, sair para trabalhar, mas que, sem embargo, geram situações de violência e precariedade. Os pescadores representam os humilhados da terra.

O segundo aspecto importante da narrativa de Aparecida é a Mãe. Maria conhece a vida dos seus filhos e os espera no rio, envolta na lama. Não está longe, mas no meio das lutas e buscas de seus filhos, sem medo. Ela "submerge com eles nos avatares da história", no meio da vida e tudo faz para renovar a esperança, sem temer sujar-se de lama.

Observemos este caráter encarnatório da graça, ou ação salvífica de Deus, através de Maria. É ressaltada a característica deste amor de Deus que "desce" e "entra" na vida humana e, indo além, "submerge" no espaço onde estão as pessoas concretas e "suja-se" com as realidades carentes de salvação para suscitar transformação e redenção.

O último aspecto ressaltado por Francisco é o encontro. As redes não se encheram de peixes, "mas de uma presença que lhes preencheu a vida e lhes deu a certeza de que não estavam sós em suas buscas e lutas", representada na pequena imagem de Maria. Aqueles homens a limparam e restauraram. Em seguida a levaram a uma casa, onde permaneceu muitos anos. Para lá acorriam outros pescadores e famílias, gerou-se uma comunidade.

Assim, o Papa Francisco ressalta a ideia de que Maria ensina a esperar os filhos ali onde eles estão. É no universo de resistência à não-vida e de luta pela vida que encontramos uma presença que nos diz que não estamos sozinhos e que a bondade e a força de Deus nos alcançam. As circunstâncias do encontro de Aparecida ensinam aos discípulos a necessidade de entrar na "lama" da existência, se preciso, para alcançar os seus filhos, especialmente os que mais necessitam. Esta é a dinâmica dos seguidores do Deus que, em Jesus Cristo, entrou na fragilidade humana, pelo sim de Maria. Fez-se escravo da humanidade, desceu à situação do mais pobre e humilhado, fez-se "carne de pecado" ( $\mathrm{Rm} 8,3)$ em solidariedade a nós para abrir um caminho novo e oferecer uma vida nova. Esta é a dinâmica que os discípulos e toda a Igreja são chamados a seguir. 
Um sim a Deus é um sim à encarnação do amor de Deus que continua acontecendo hoje, no Espírito. Deus quis contar com Maria, e quer contar com todos: "segue-me", é o seu mandato, em Cristo. "Vós sois o sal da terra" (Mt 5,13).

Não há receitas prontas, mas critérios, pequenas certezas que surgem dos encontros. O Deus de Jesus Cristo, a quem nos leva o Espírito, não concede a pesca, assim como não transforma as pedras em pão. Ele está conosco, em nós e em nosso meio, suscitando vida nova. Mas é preciso, como Maria, ter olhos para ver este mistério, coração para acolhê-lo e coragem para gerar dinâmicas novas em nossos espaços de vida, mesmo que, para isto, como no evento de Aparecida, a Igreja tenha que se sujar com a lama do rio e das estradas.

Pela força de seu testemunho, Maria continua dando voz aos pobres. Uma visita aos santuários marianos nos faz ver claramente esta realidade. Através de Maria, os pobres cantam as maravilhas de Deus em suas vidas, seus milagres de vida nova, de forma realista e esperançada. E, ao mesmo tempo proclamam a esperança no Deus da promessa, que está do lado deles. Esta proclamação é para todos um grito por justiça e vida, à qual a Igreja, como Povo de Deus, deve estar alerta, esvaziada de qualquer autorreferencialidade e em atitude de caminho e de "saída", ${ }^{32}$ se quiser ser, como Maria, discípula de Jesus.

\section{Conclusões}

1. A teologia mariana vê em Maria a expressão da lógica encarnatória da ação salvífica de Deus. Pela encarnação, Deus se humaniza, "desce", "entra", "submerge" em nossa humanidade histórica e culturalmente enraizada. Em Jesus Cristo, Deus faz-se escravo, transpassa a humanidade humilhada para instaurar dinâmicas de uma vida nova. Assim, a vida de Maria, em que ecoa esta lógica de encarnação, pode inspirar a espiritualidade e o discipulado.

2. A narrativa evangélica da Anunciação e, nela, a saudação do anjo a Maria, nos mostra que a graça de Maria, a mãe do Senhor, foi servir à humanização de Deus. Esta graça da concepção não é um objeto ou uma função, mas sim uma relação radical com o Filho que, no Espírito, assume a humanidade no seio de Maria. Relação que se desenvolve ao longo de toda a vida de Maria, da concepção à cruz, da cruz à participação na Igreja nascente

\footnotetext{
32 PAPA FRANCISCO. "Exortação Apostólica Evangelii Gaudium”, n. 20. Disponível em: $<$ https://w2.vatican.va/content/francesco/pt/apost_exhortations/documents/papa-francesco_ esortazione-ap_20131124_evangelii-gaudium.html>. Acesso em 24 de maio de 2017.
} 
e que perpetua ao longo dos tempos, na glória. A teologia mariana convida toda a teologia a contemplar e refletir sobre esta vida concreta, humana, da jovem de Nazaré, na relação com o seu filho, para, a partir daí, aprofundar na "escandalosa" imagem de Deus que dela emana - um Deus que se faz fragilidade humana.

3. A Igreja antiga entendeu a maternidade de Maria como o meio escolhido por Deus para o abaixamento, Kénosis, de Deus até nós. Deus se faz, nas palavras de Hipólito, "de nossa mesma massa", a massa de Maria, com vistas a uma nova criação. Maria entrará na história da fé cristã por este mistério da humanização do Verbo de Deus, em Jesus, como mostram os antigos símbolos apostólicos, o Símbolo dos Apóstolos e o Símbolo NicenoConstantinopolitano (ano 381). A teologia mariana, no aprofundamento de seus dogmas, especialmente no dogma da Theotokos, "Mãe de Deus", associa esta autocomunicação de Deus na encarnação à autoentrega de Maria a este desígnio salvífico, na fé, em corpo, mente e espírito.

4. O assentimento de Maria ao convite divino de ser a mãe do Salvador constitui um processo de humanização e amadurecimento da mulher Maria. Características deste processo são o engajamento em uma missão profética, a acolhida da vida no Espírito em todas as suas dimensões - corpo, mente e espírito -, o desenvolvimento da liberdade interior que se expressa em ações assumidas responsavelmente, a capacidade de acolher o dom de Deus em meio às lutas da existência concreta, um diálogo gerador de audácia, lucidez e esperança.

5. O mesmo princípio da encarnação orienta a espiritualidade cristã. Como Maria, os cristãos geram em seu coração o Cristo vivo, cujo Espírito já os habita, e o encarnam no mundo. A grande vocação da espiritualidade cristã, dos discípulos e missionários de Cristo é acolher o amor de Deus e buscar os caminhos concretos da encarnação deste amor salvador nas mediações aparentemente tão prosaicas e intranscendentes da vida, como podem ser as mediações familiares, amorosas, comunitárias, sociais, econômicas ou políticas. Maria será sempre o símbolo de uma fé que se encarna e lembrará que o cristianismo é a religião da encarnação. A teologia mariana é chamada a não se esquecer desta dimensão fundamental da espiritualidade.

6. O evento do encontro da imagem de N. Sra. Aparecida, há 300 anos, transforma-se em metáfora da Igreja que assume a dinâmica encarnatória da ação divina. O Papa Francisco observa que a imagem, encontrada na lama do rio onde pescavam os pobres pescadores, simboliza a Igreja que desce às realidades mais necessitadas, sem medo de se sujar na lama do rio para aí 
encontrar os seus filhos. Para isso, deixa a autorreferencialidade para assumir, em seu testemunho, a força de ser uma Igreja "em saída".

7. É preciso trazer Maria para a terra dos vivos. Grande louvor à Mãe de Deus é a renovação da imagem de Deus, na direção do Deus de Jesus Cristo. Ele se faz pequeno e frágil no seio da mulher Maria e, a partir de dentro desta humanidade, instaura dinâmicas de vida nova que transfiguram a realidade. Um Deus que, assim como interpelou a liberdade e o amor de Maria para fazer possível a encarnação, também hoje interpela nosso amor e liberdade para que, em nossa fragilidade e pequenez, na obscuridade das realidades tão massacradas pela corrupção, pela indiferença e pela religião de prestígio e consumo, possamos hoje dizer sim às muitas formas de encarnação do seu amor.

8. Tudo isto aponta para a revalorização da figura de Maria nas igrejas - esta revalorização possui virtualidade ecumênica - para a atualização dos significados da confissão cristã de que Deus, na plenitude dos tempos, enviou ao mundo o seu Filho, nascido de mulher. A vida espiritual e a vida das igrejas, em nosso hoje, podem ser revitalizadas pela teologia mariana.

\section{Referências bibliográficas}

BINGEMER, M. C.; GEBARA, I. Maria, Mãe de Deus e mãe dos pobres. Petrópolis: Vozes, 1987.

BOFF, C. Mariologia Social. O significado da Virgem para a Sociedade. São Paulo: Paulus, 2006.

BROWN, R. E. O nascimento do Messias: comentários das narrativas da infância nos evangelhos de Mateus e Lucas. São Paulo: Paulinas, 2005.

CONFERÊNCIA GERAL DO EPISCOPADO LATINO-AMERICANO. $A$ Evangelização no presente e no futuro da América Latina. Conclusões: PUEBLA (texto oficial da CNBB; apresentação didática: Pe. J. B. Libânio). $5^{\text {a }}$ ed., São Paulo: Loyola, 1979.

DENZINGER, H. Compêndio dos símbolos, definições e declarações de fé e moral (atualizada por J. Konings, com base na 43a ed. alemã [2010], preparada por P. Hünermann e H. Hoping), $2^{\mathrm{a}}$ ed. rev. e ampl. São Paulo: Paulinas/Loyola, 2013.

GARCIA PAREDES, J. C. R. Mariologia. Síntese bíblica, histórica e sistemática. São Paulo: Ave-Maria, 2011. 
GESCHÉ, A. Deus. São Paulo: Paulinas, 2004.

JOHNSON, E. Nossa verdadeira irmã. Teologia de Maria na comunhão dos santos. São Paulo: Loyola, 2006.

KASPER, W. A Igreja católica. Essência, realidade, missão. São Leopoldo: UNISINOS, 2012

MIRANDA, M. F. A salvação de Jesus Cristo: a doutrina da graça. São Paulo: Loyola, 2004.

MUlLER, A.; SATTLER, D. "Mariologia". In: SCHNEIDER, T. (Org.). Manual de Dogmática. Vol. II. $4^{\text {a }}$ ed. Petrópolis: Vozes, 2009, pp. 143-170.

MURAD, A. Maria, toda de Deus e tão humana: compêndio de Mariologia. São Paulo/Aparecida: Paulinas/Santuário, 2014, pp. 140-141.

PAPA FRANCISCO. "Carta a los participantes em la XXXVI Asamblea General del Consejo Episcopal Latinoamericano" (CELAM, 9-12/05/17, San Salvador). Disponível em: <http://w2.vatican.va/content/francesco/ es/letters/2017/documents/papa-francesco_20170508_lettera-plenariacelam.html>. Acesso em 13 de maio de 2017.

PAPA FRANCISCO. "Exortação Apostólica Evangelii Gaudium". Disponível em: <https://w2.vatican.va/content/francesco/pt/apost_ exhortations/documents/papa-francesco_esortazione-ap_20131124_ evangelii-gaudium.html $>$. Acesso em 24 de maio de 2017.

PEDROSA-PÁDUA, L. “Itinerários de Maria. Inspiração para uma Igreja 'em saída"”. Convergência 481 (2015), pp.321-335.

TEMPORELLI, C. Maria, mulher de Deus e dos pobres. Releitura dos dogmas marianos. São Paulo: Paulus, 2010.

\section{Lúcia Pedrosa-Pádua}

Doutora em Teologia Sistemático-Pastoral pela Pontifícia Universidade

Católica do Rio de Janeiro Professora de Teologia na Pontifícia Universidade Católica do Rio de Janeiro, na Graduação e Pós-Graduação

Rio de Janeiro / RJ - Brasil

E-mail: lpedrosa@puc-rio.br 